\title{
Antibacterial activity of CTAB-modified zeolite NaY with different CTAB loading
}

\author{
Mashitah Mad Salim, Nik Ahmad Nizam Nik Malek*, Nur Isti'anah Ramli, Siti Aishah Mohd Hanim and Salehhuddin Hamdan \\ Department of Biotechnology \& Medical Engineering, Faculty of Biosciences and Medical Engineering, Universiti Teknologi Malaysia, 81310 UTM, Johor Bahru, Johor, \\ Malaysia. \\ *Corresponding Author: niknizam@fbb.utm.my (Nik Ahmad Nizam Nik Malek)
}

\section{Article history :}

Received 11 February 2014

Revised 15 March 2014

Accepted 30 May 2014

Available online 30 June 2014

\section{GRAPHICAL ABSTRACT}

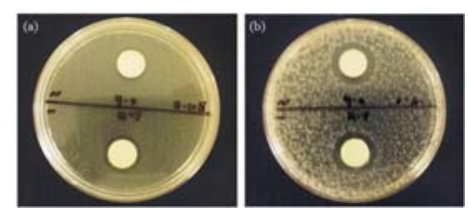

\section{ABSTRACT}

The antibacterial activity of cetyltrimethyl ammonium bromide (CTAB) - modified Zeolite NaY against Escherichia coli and Staphylococcus aureus was examined in agar disk diffusion (Kirby-Bauer) method. The diameter of the inhibition zones for E. coli and S. aureus, increased from 1.5 to $1.7 \mathrm{~cm}$ and 1.9 to 2.0 $\mathrm{cm}$, respectively, with the increasing concentrations of CTAB adsorbed on Zeolite NaY from percent coverage of the External Cation Exchange Capacity of Zeolite NaY: 0.5 to 5.0. CTAB-modified Zeolite $\mathrm{NaY}$ showed effective antimicrobial activity against $S$. aureus compared to $E$. coli.

Keywords: Cetyltrimethyl ammonium bromide (CTAB), Zeolite NaY, Cation Exchange Capacity, Escherichia coli, Staphylococcus aureus

\section{INTRODUCTION}

Due to the outbreak of the infectious diseases caused by different pathogenic bacteria and development of antibiotic resistance, pharmaceutical companies and researchers are searching for new antibacterial agents. Immobilized antimicrobial agents on inert materials such as zeolites and clays gave a great interest as they have some advantages; (1) preventing patient exposure to biocides solutions,(2) lowering their irritant properties, and (3) prolong the duration of antibacterial efficacy [1].

Zeolites are crystalline hydrated aluminosilicate with their structure is based on an infinitely extended threedimensional network consisting of $\left[\mathrm{AlO}_{4}\right]^{5-}$ and $\left[\mathrm{SiO}_{4}\right]^{4-}$ connected mutually via oxygen atoms. The substitution of $\mathrm{Al}^{3+}$ for $\mathrm{Si}^{4+}$ in zeolite framework results in negatively charged aluminosilicate lattice. Hence, inorganic metal cations such as $\mathrm{Na}^{+}, \mathrm{K}^{+}, \mathrm{Ca}^{2+}$ and $\mathrm{Mg}^{2+}$ are presented in the zeolite framework to neutralize the aluminosilicate lattice of zeolite. The cations are movable and exchangeable by other cations [2] and thus, zeolite having low $\mathrm{Si} / \mathrm{Al}$ ratio resulted in high cation exchange capacity [3].

Quaternary ammonium compounds (QACs) are kind of biocides which are used in household products. Due to its broad spectrum antibacterial characteristics, they also have been applied in pharmaceutical, water treatment and antifungal treatment for crops [4]. In general, QACs are chemically stable within $\mathrm{pH} 3$ to $\mathrm{pH} 9$ [5] and show antimicrobial activity with chain length composed of 8 to 18 carbon atoms [6]. Since cetyltrimethyl ammonium bromide (CTAB) has 16 carbon atoms on its hydrocarbon tail, it was used to modify Zeolite NaY surfaces in this study.

It is well known that QAC functions as a cationic surface-active agent having antimicrobial activity due to cellular disruption of the cell membrane $[6,7,8]$. QAC displays antimicrobial activity even after being covalently immobilized on inert supports [9]. Immobilized surfactant (CTAB) on natural zeolite has been shown to inactivate viruses and bacteria [10]. Preliminary results for the combination of QAC and zeolite have shown promise for their combined antimicrobial efficacy [11]. QAC as a cationic surfactant reduces the surface tension at interfaces and is attracted to negatively charged surfaces, including zeolites and microorganisms. Quaternary ammonium ions act by penetrating the cell membrane causing leakage of cell components, disruption of the bacterial metabolism, inhibition of cell growth, and cell death [12].

Staphylococcus aureus is one of the most common causes of foodborne disease and it is also an infectious pathogen. Staphylococci are frequently found on surfaces in hospitals, households, and in the food industry. S. aureus present on surfaces or equipment may be a source of crosscontamination of food. As other Gram positive bacteria, staphylococci are relatively tolerant to desiccation and may survive on open surfaces for long periods [13]. E. coli as a representative of fecal, facultative anaerobic microorganism was used to represent Gram negative bacteria. 
The aim of this work was to prepare CTAB-modified Zeolite $\mathrm{NaY}$ with different $\mathrm{CTAB}$ loading and to observe the effects of different CTAB loading on Zeolite $\mathrm{NaY}$ on the antibacterial activity against E. coli and $S$. aureus. In this study, a good carrier system from Zeolite $\mathrm{NaY}$ was used because of its relatively high ion exchange capacity and lattice stability [14]. Zeolite $\mathrm{NaY}\left(\mathrm{SiO}_{2} / \mathrm{Al}_{2} \mathrm{O}_{3}\right.$ ratio: 5.1) was loaded with CTAB, a QAC by the ion exchange method. Zeolites having a specific surface area at least 150 $\mathrm{m}^{2} / \mathrm{g}$ with $\mathrm{Si} / \mathrm{Al}$ ratio below 14 are suitable to be used as a carrier for antibacterial agents [15]. Because of its large size, the cationic surfactant was unable to penetrate into the zeolite framework, thus the surfactant molecules were occupied on the surface of Zeolite $\mathrm{NaY}$ by ion exchange with the $\mathrm{Na}^{+}$on zeolite surface. Increasing the concentrations of $\mathrm{CTAB}$ in the solution will increase the amount of cationic surfactant loaded onto Zeolite NaY.

\section{EXPERIMENTAL}

\subsection{Materials}

The commercial Zeolite $\mathrm{NaY}$ was supplied by Zeolyst International (CBV 100) with a $\mathrm{SiO}_{2} / \mathrm{Al}_{2} \mathrm{O}_{3}$ mole ratio 5.1; nominal cation in sodium form $\left(\mathrm{Na}_{2} \mathrm{O}\right.$ weight $(\%)$ : 13.0); while the unit cell size $24.65 \AA$ and surface area 900 $\mathrm{m}^{2} / \mathrm{g}$. The external cation exchange capacity (ECEC) of Zeolite $\mathrm{NaY}$ was 0.53 mequiv/g [16]. Cetyltrimethyl ammonium bromide (CTAB) was supplied by MerckSchuchardt.

\subsubsection{Modification of Zeolite NaY with CTAB}

Eight series of CTAB-modified Zeolite $\mathrm{NaY}$ were prepared by reacting zeolite with $\mathrm{CTAB}$ in aqueous solutions. CTAB was added in an amount equal to $0.5,0.7$, 1.0, 1.5, 2.0, 3.0, 4.0 and 5.0 of ECEC of zeolite. This experiment was designed to study the effect of different surface coverage of CTAB onto the zeolite; in the antibacterial activity against pathogenic bacteria of $E$. coli and S. aureus. For example, the preparation of CTABmodified Zeolite NaY (ECEC: 0.5) needed $0.1932 \mathrm{~g}$ of CTAB to saturate $50 \%$ of the ECEC Zeolite NaY (2 g). The calculation of the amount of CTAB needed was shown below:

ECEC of Zeolite $\mathrm{NaY}=53.0 \mathrm{meq} / 100 \mathrm{~g}$.

Molecular weight of CTAB $=364.46 \mathrm{~g} / \mathrm{mol}$.

For $1 \mathrm{meq} / 100 \mathrm{~g}=6.02 \times 10^{20}$ adsorption sites.

$$
\begin{aligned}
& =1 \mathrm{mmol} / 100 \mathrm{~g} . \\
& =0.01 \mathrm{mmol} / \mathrm{g}=1.0 \times 10^{-5} \mathrm{~mol} / \mathrm{g} .
\end{aligned}
$$

Hence, $1 \mathrm{~g}$ of Zeolite $\mathrm{NaY}$ with ECEC $=53 \mathrm{meq} / 100 \mathrm{~g}$ can be satisfied with $5.3 \times 10^{-4} \mathrm{~mol}$ of cations to achieve $100 \%$ satisfaction.

Amount of CTAB needed:

$=0.50 \times 2 \mathrm{~g} \times 5.3 \times 10^{-4} \times 364.46 \mathrm{~g} / \mathrm{mol}$.

$=0.1932 \mathrm{~g} \mathrm{CTAB}$.
CTAB solution was prepared by dissolving an appropriate amount of CTAB in double distilled water and was heated gently until all CTAB was dissolved. After that, the CTAB solutions were mixed with zeolite and the mixture was stirred using a magnetic stirrer for 16 hours at room temperature. The mixture was then filtered by Whatman (No. 2) filter paper and the solid samples were dried at $70^{\circ} \mathrm{C}$ overnight. The resultant products were readily used for antibacterial test.

\subsubsection{Determination of adsorbed CTAB on zeolite}

The CTAB concentrations in the solution were determined by UV-Visible Spectrophotometer. However, prior to the determination of $\mathrm{CTAB}$ concentrations, the solution needs to be complexed by acid orange 7 (orange II) dye since CTAB alone cannot be detected by the UVVisible Spectrophotometer [17]. The acidic condition is needed in order for the CTAB molecules to bind to the dye forming CTAB-dye and these compounds are soluble in chloroform. The acid orange dye alone was not soluble in chloroform, but soluble in water. About $25 \mathrm{ml}$ of distilled water (DW), $5 \mathrm{ml}$ of sulfuric acid $\left(\mathrm{H}_{2} \mathrm{SO}_{4}, 2 \mathrm{M}\right)(\mathrm{QRec})$ and $10 \mathrm{ml}$ of chloroform (QRec) were mixed in the separating funnel. About $2 \mathrm{ml}$ of acid orange 7 (orange II, $1 \mathrm{mM}$ ) was then added to the previous mixture and shaken. Then, $1 \mathrm{ml}$ of the solution sample was added, vigorously shaken and chloroform layer was extracted and ready for the next analysis. The standard solutions of CTAB were prepared in the range of 0.2 to $1.0 \mathrm{mM}$. The extracted chloroform from the samples was measured by UV-Vis at absorbance $\lambda_{487 \mathrm{~nm}}$ using the Vis Spectrophotometer (NANOCOLOR VIS, Macherey Nagel).

The adsorption study was carried out by batch method. The amount of CTAB adsorbed on Zeolite NaY was calculated from the difference in concentrations of CTAB before and after the adsorption on zeolite. The adsorbed amounts were determined by using the following equation:

$$
\mathrm{Q}=\left(\left(\mathrm{C}_{\mathrm{i}-} \mathrm{C}_{\mathrm{eq}}\right) \mathrm{V}\right) / \mathrm{m}
$$

Where $\mathrm{Q}$ is the adsorbed amount in $\mathrm{mmol} / \mathrm{kg}, \mathrm{C}_{\mathrm{i}}$ is the initial concentration of CTAB before the adsorption in $\mathrm{mmol} / \mathrm{L}$, $\mathrm{C}_{\mathrm{eq}}$ is the equilibrium concentration of CTAB in $\mathrm{mmol} / \mathrm{L}, \mathrm{V}$ is the volume of the solution in $\mathrm{L}$, and $\mathrm{m}$ is the amount of Zeolite NaY.

\subsubsection{FTIR characterization of CTAB-modified Zeolite $\mathrm{NaY}$}

FTIR Spectroscopy was used to examine the presence of surfactant (CTAB) molecules on zeolite. Thermo Scientific Nicolet iS5 with Smart iTR Diamond crystal FT-IR (Fourier Transform-Infrared) spectrometer was used to obtain IR spectra. The FT-IR spectra of the samples were obtained from 550 to $4000 \mathrm{~cm}^{-1}$ by 
accumulating 16 scans at a resolution $4 \mathrm{~cm}^{-1}$ by $\mathrm{KBr}$ method and FTIR spectrum was recorded using OMNIC software.

\subsubsection{Antibacterial activity testing}

The antibacterial activity of the CTAB-modified Zeolite $\mathrm{NaY}$ was tested against E. coli and S. aureus by slightly modified the disk diffusion test according to the National Committee for Clinical Laboratory Standards [18]. The stock culture of both bacteria has been obtained from Institute of Medical Research (IMR), Malaysia. The tests were accomplished in duplicate. The bacteria were cultured on Nutrient Agar (NA) at $37{ }^{\circ} \mathrm{C}$ for $24 \mathrm{~h}$; three to five colonies were diluted with sterile saline solution $(0.9 \%)$ and the suspension was adjusted to $0.5 \mathrm{McF}$ arland turbidity (1.5 $\left.\times 10^{8} \mathrm{CFU}\right)$. A sterile cotton swab was used to inoculate the surface of another NA plate, rotating the plate every $60^{\circ}$ to ensure homogenous growth. The synthetic and treated samples $(0.3 \mathrm{~g})$, with and without CTAB, were pressed into pellets (13 mm diameter) and placed over the surface of the agar plates. The width of inhibition was measured after 24 $\mathrm{h}$ of incubation at $37^{\circ} \mathrm{C}$.

\section{3}

\section{RESULTS \& DISCUSSION}

\subsection{Adsorption of CTAB on Zeolite NaY with Different CTAB Loading}

The external cation exchange capacity (ECEC) is a measurement of the negative charges on zeolite external surface. Because of the large molecular size of surfactant molecules (CTAB), these molecules cannot enter the angstrom sized pore of the zeolite, instead will exchange with $\mathrm{Na}^{+}$on the external surface of the Zeolite $\mathrm{NaY}$. Different concentrations of surfactant molecules in aqueous solution will give different ECEC coverage of the surfactant molecules on zeolite surface. Fig. 1 shows the amount of CTAB adsorbed on Zeolite $\mathrm{NaY}$ with different $\mathrm{CTAB}$ loading.

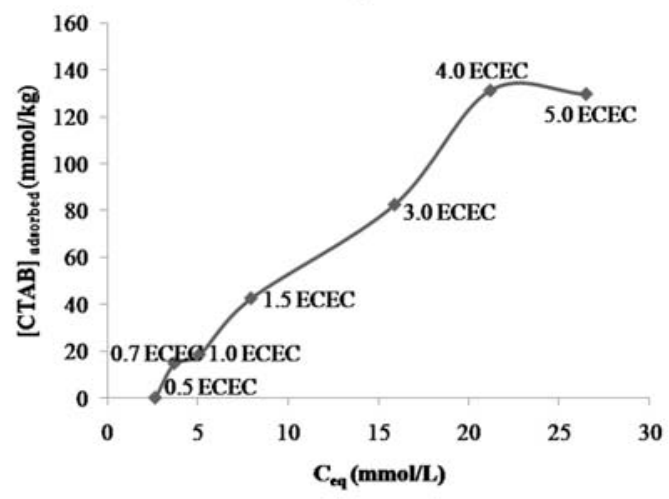

Fig. 1 Adsorption of $\mathrm{CTAB}$ on Zeolite $\mathrm{NaY}$ from aqueous solution.

According to Fig. 1, an increase in the equilibrium concentration of CTAB in solution from surfactant coverage
0.5 to $4.0(2.65-21.20 \mathrm{mmol} / \mathrm{L})$; would increase the amount of surfactant molecules adsorbed onto Zeolite NaY. The steep slope obtained reflects the high affinity of adsorbate (surfactant molecules) adsorbed onto adsorbent (Zeolite $\mathrm{NaY}$ ). Based on theory, at the ECEC coverage of 0.5-0.7, surfactant cations were in the form of partial-monolayer on zeolite surface, at the ECEC coverage of 1.0, surfactant cations were in the form of complete-monolayer, at the ECEC coverage of 1.5, surfactant cations were in the form of partial-bilayer and at the ECEC coverage of 2.0, surfactant cations were in the form of complete-bilayer [19]. At low concentration of surfactant (ECEC: < 1.0), the cationic surfactant molecules were adsorbed on negative charges of zeolite surface by ion-exchange, while increasing the concentration of surfactant (ECEC: $>1.0$ ), the cationic surfactant molecules were adsorbed on the zeolite surface by hydrophobic bonding to the alkyl chain of the first layer of surfactant molecules [19]. At surfactant coverage more than twice ECEC (ECEC > 2.0), the adsorption of surfactant molecules on zeolite surface create hemimicelle aggregates more than as bi-layer [20]. There are variety of sizes and shapes of the aggregates such as patchy bi-layer, small spherical micelle as well as multi-layer [21]. At this point, the adsorption of surfactant molecules on Zeolite $\mathrm{NaY}$ are unstable as it is loosely bound to Zeolite NaY surface and tend to release back into the solution [16]. In this study, the adsorption of surfactant molecules on the Zeolite $\mathrm{NaY}$ continuing increase above surfactant coverage (ECEC: $>$ 2.0) until it reaches surfactant coverage (ECEC: 4.0). The graph reached saturation at the surfactant coverage of ECEC 4.0 to $5.0(21.20-26.51 \mathrm{mmol} / \mathrm{L})$. Therefore, increase the amount of surfactant molecules in working solution does not increase the amount of surfactant loaded onto Zeolite $\mathrm{NaY}$.

\subsection{Characterization of CTAB-Modified Zeolite NaY by FTIR}

The FTIR spectra at a region of 3500 to $2500 \mathrm{~cm}^{-1}$ for CTAB-modified Zeolite NaY with different ECEC coverage $(0.5,0.7,1.0,1.5,2.0,3.0,4.0,5.0)$ that have been compared with that of parent Zeolite $\mathrm{NaY}$ can be seen in Fig. 2.

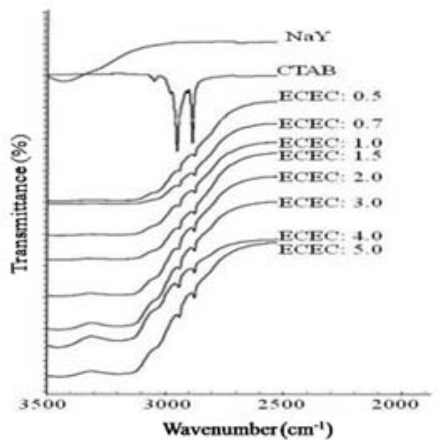

Fig. 2 FTIR spectra of CTAB-modified Zeolite NaY with different CTAB coverage of ECEC Zeolite NaY.

The two significance peaks appeared as an indicator that the CTAB molecules have been successfully attached on parent zeolite [22]. FTIR spectra of CTAB-modified 
Zeolite $\mathrm{NaY}$ showed the emergence of 2 additional peaks between 2800 and $2900 \mathrm{~cm}^{-1}$ but absent in the FTIR spectra of the parent zeolite. This indicates the presence of CTAB molecules on the zeolite surface. CTAB comprises of two parts; positive charge of ammonium hydrophilic head and another one is a long chain of hydrocarbon tail. The positive charge head can be attached to the negative sites of zeolite frameworks leaving the outer layer with long chains of hydrocarbon tail. Hence, two additional peaks that were observed in FTIR spectra were assigned to the C-H bonding of long chain hydrocarbon tail.

This result is in agreement with other papers where peaks in the FTIR spectra around 2849 and $2916 \mathrm{~cm}^{-1}$ were assigned to the symmetric and the asymmetric stretching mode of C-H in CTAB molecules [23]. Therefore, FTIR spectra in Fig. 2 revealed the successful attachment of CTAB molecules on Zeolite NaY.
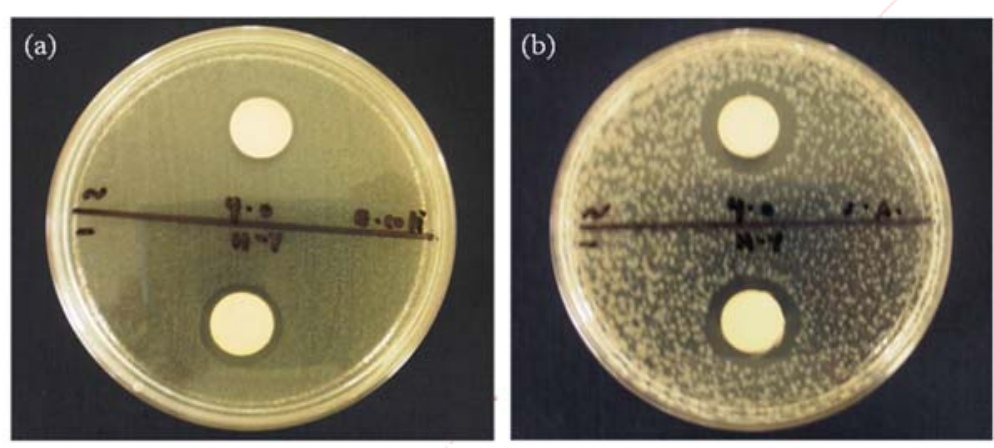

Fig. 3 Optical images of (a) CTAB (ECEC: 4.0)-modified Zeolite NaY on E. coli and (b) CTAB (ECEC: 4.0)-modified Zeolite NaY on S. aureus streaked agar plates after $24 \mathrm{~h}$ incubation.

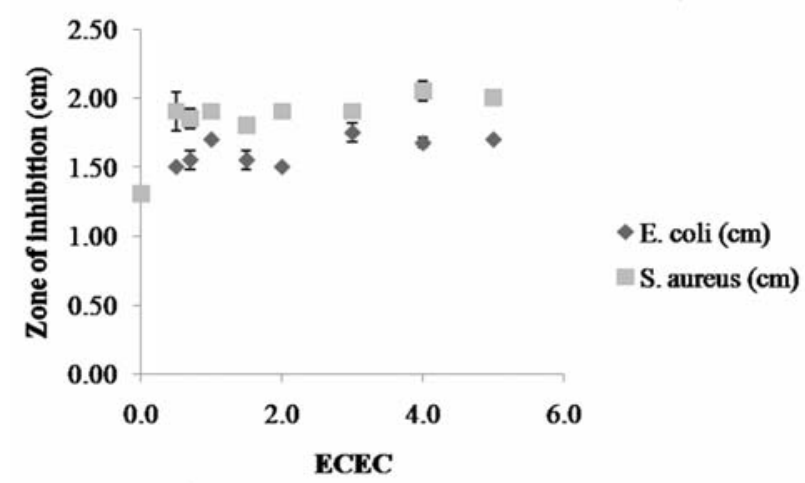

Fig. 4 Inhibition zone values as a function of CTAB-modified Zeolite NaY concentrations against E. coli and S. aureus. Each point represents an average of duplicate measurements.

The results of the antibacterial activity tests indicated that parent Zeolite $\mathrm{NaY}$ has very low antibacterial activity against both $E$. coli and $S$. aureus whereas antibacterial activities of CTAB-modified Zeolite $\mathrm{NaY}$ were effective against both bacteria. Generally, increased in the ECEC coverage of CTAB-modified Zeolite $\mathrm{NaY}(0.5,0.7,1.0,1.5$, 2.0, 3.0, 4.0, 5.0) would increase the diameter of inhibition

\subsection{Antibacterial Activity of CTAB-Modified Zeolite NaY}

The antibacterial activities of CTAB-modified Zeolite NaY with different CTAB coverage of Zeolite NaY was carried out by using disk diffusion (Kirby-Bauer) method where the diameter of the zone of inhibition was measured to determine their antibacterial activities. The bacteria $E$. coli and $S$. aureus were used to represent the Gram negative and Gram positive bacteria, respectively. An example of the optical image of the bacteria plate containing disks of CTAB-modified Zeolite NaY after incubation for 24 hours can be seen in Fig. 3 while the diameter of inhibition zone against the coverage of CTAB according to ECEC of Zeolite $\mathrm{NaY}$ is given in Fig 4. 
ECEC $0.5,1.0,1.5,2.0$ respectively surfactant coverages on Zeolite $\mathrm{NaY}$ surface were in the formed of partialmonolayer, complete-monolayer, partial-bilayer and complete-bilayer as mentioned before [19]. However, at higher CTAB levels (ECEC: > 2.0), CTAB molecules that loosely bound from admicelles on the CTAB-modified Zeolite $\mathrm{NaY}$ was released into the aqueous solution [16] containing bacterial cell culture. This behavior has been indicative of the adsorption of CTAB cationic surfactant through hydrophobic interactions since adsorption through ion exchange (ECEC: $\leq 1.0$ ) is almost irreversible [12]. Thus, the antibacterial activity of CTAB-modified Zeolite $\mathrm{NaY}$ with cationic surfactant coverage of 0.5 to 1.5 as shown in Fig. 4 was due to the localized of bacterial cells on CTAB-modified Zeolite NaY whilst at surfactant coverage of CTAB-modified Zeolite NaY ECEC $\geq 2.0$, the antibacterial activity was due to the released $\mathrm{CTAB}$ molecules onto the NA plates containing colonies of bacteria (E. coli and S. aureus).

\section{CONCLUSIONS}

(1) For all samples, the amount of CTAB adsorbed increased with increasing initial concentration of the surfactant. At low concentrations, the adsorption process is driven primarily by cation exchange. At high concentrations, surfactant cations are adsorbed via Van der Waals interactions and by the interaction of the hydrocarbon chain with adsorbed $\mathrm{CTAB}$ on external surface of the Zeolite $\mathrm{NaY}$.

(2) Generally, the increasing of the ECEC of CTABmodified Zeolite NaY (0.5-5.0) increased the inhibition zones for both of the bacteria (E. coli and $S$. aureus). However, compared to E.coli, S. aureus was more susceptible to CTAB-modified Zeolite NaY.

\section{ACKNOWLEDGEMENT}

The work is funded by Research University Grant (RUG) UTM, Tier 2 (Vot No: 05J05), Sciencefund from MOSTI (SF-01-06-SF0994) and Zamalah Scholarship provided by Universiti Teknologi Malaysia and the Ministry of Education (MoE) Malaysia.

\section{REFERENCES}

[1] J.-B.D. Green, T. Fulghum, M.A. Nordhous, Science against microbial pathogens: communicating current research and technological advances, In: Mendez-Vilas, A. (Ed.), Microbiology Book Series-Number 3, vol. 1, Formatex Research Center, 2011, p. 84-98

[2] J. Hrenovic, J. Milenkovic, T. Ivankovic, N. Rajic, J. Hazard. Mater., 201-202 (2012) 260.

[3] D.W. Breck, Zeolite Molecular Sieves: structure, chemistry, and use, John Wiley \& Sons, Canada, 1974, p. 536

[4] K. Hegstad, S. Langsrud, B.T. Lunestad, A.A. Scheie, M. Sunde, S.P. Yazdankhah, Microb. Drug Resist.16 (2010) 91.

[5] D.L. Dyer, K.B. Gerenraich, US Patent 5994383 (1999)

[6] A.J. Isquith, E.A. Abbott, P.A. Waters, Appl. Microbiol., 24 (1972) 859.

[7] W.B. Hugo, J. Appl. Bacteriol., 30 (1967) 27.

[8] A.N. Petrocci, Surface-active reagents: quaternary ammonium compounds. in: S.S. Block (Ed.) Disinfection sterilization and preservation, Lea and Febiger, Philadelphia, PA, 1983, p. 309

[9] I.-F. Tsao, H.Y. Wang, C. Jr. Shipman, Biotechnol. Bioeng. 34 (1989) 639.

[10] D. Schulze-Makuch, R.S. Bowman, S.D. Pillai, H. Guan, Ground Water Monit. R., 23(4) (2003) 68.

[11] M. Abbaszadegan, B. Mayer, N. Ryu, N.H. Nwachuku, J. Environ. Sci. Heal., 41 (2006) 1201.

[12] G. Ozdemir, S. Yapar, M.H. Limoncu, Appl. Clay Sci., 72 (2013) 201.

[13] T. Moretro, G.S. Hoiby-Pettersen, C.K. Halvorsen, S. Langsrud, Food Control, 28 (2012) 118.

[14] H.-H. Cheng, C.-C. Hsieh, C.-H. Tsai, Aerosol Air Qual. Res., 12 (2012) 409.

[15] Z. Hagiwara, S. Hoshino, H. Ishino, S. Nohara, K. Tagawa, K. Yamanaka, US Patent 4911899 (1990)

[16] A.M. Yusof, N.A.N.N. Malek, J. Hazard. Mater. 162 (2009) 1019.

[17] G.V. Scott, Anal. Chem., 40 (1968) 768.

[18] National Committee for Clinical Laboratory Standards, Performance standards of antimicrobial disk susceptibility test, Approved Standard M02-A8, Wayne, PA: NCCLS, 2000

[19] H.-P. Chao, S.-H. Chen, Chem. Eng. J., 193-194 (2012) 283.

[20] M. Ghiaci, R. Kia, A. Abbaspur, F. Seyedeyn-Azad, Sep. Purif. Technol., 40 (2004) 285.

[21] M. Ghiaci, A. Abbaspur, R. Kia, F. Seyedeyn-Azad, Sep. Purif. Technol., 40 (2004) 217.

[22] N.A.N.N. Malek, N.S. Malek, in $2^{\text {nd }}$ International Conference on Chemistry and Chemical Process (ICCCP), APCBEE Procedia 3, 56 May 2012, Kuala Lumpur, Malaysia, 2012, p. 134-139

[23] Z. Li, L. Gallus, Appl. Clay Sci., 35 (2007) 250.

[24] O. Yousheng, X. Yushan, T. Shaozao, S. Qingshan, C. Yiben, J. Rare Earth, 27 (2009) 858.

[25] P. Herrera, R.C. Burghardt, T.D. Phillips, Vet. Microbiol. 74 (1999) 259. 